\title{
PENGEMBANGAN SOP BERBASIS INFOGRAFIS JENIS - JENIS PENELITIAN UNTUK PERKULIAHAN METODOLOGI PENELITIAN PENDIDIKAN
}

\author{
I Putu Agra Arimbawa1), Ketut Agustini2), Gede Saindra Santyadiputra ${ }^{3)}$ \\ ${ }^{1}$ Teknik dan Kejuruan, Universitas Pendidikan Ganesha (penulis 1) \\ email: 1215051040@undiksha.ac.id \\ 2 Teknik dan Kejuruan, Universitas Pendidikan Ganesha (penulis 2) \\ email: ketutagustini@undiksha.ac.id \\ 3 Teknik dan Kejuruan, Universitas Pendidikan Ganesha (penulis 3) \\ email: gsaindras@undiksha.ac.id
}

\begin{abstract}
Abstrak
Penelitian ini bertujuan untuk merancang dan mengimplementasikan hasil rancangan video SOP Jenis-Jenis Penelitian Untuk Perkuliahan Metodologi Penelitian Berbasis Animasi Infografis. Pengembangan video ini bertujuan untuk memberikan informasi seputar Standard Operating Procedure (SOP) Penelitian kepada semua civitas akademika yang ingin / sedang mempelajari metodologi penelitian pendidikan. Metode yang digunakan adalah penelitian dan pengembangan (research and development), untuk mengembangkan Jenis - Jenis Penelitian Untuk Perkuliahan Metodologi Penelitian Berbasis Animasi Infografis. Model yang digunakan dalam membangun teknologi ini adalah dengan mengadopsi Model ADDIE. Adapun tahapan dalam model ADDIE ini adalah Analysis (analisis), Design (desain), Development (pengembangan), Implementation (implementasi), dan Evaluation (evaluasi). Hasil dari model ADDIE adalah pada tahap analisis dilakukan analisis masalah dan soluse, kemudian pada tahap desain dilakukan perancangan storyboard, karakter dan layout, pada tahap development dilakukan perekaman, modeling karakter, texturing, rigging,animation dan rendering dan dilanjutkan dengan tahap editing, kemudian tahap implementasi dilakukan pengujian ahli isi, media dan uji lapangan dan terakhir pada tahap evaluasi dilakukan pada setiap tahapan pengembangan. Dari tahapan pengembangan hasil akhir dari proyek ini adalah berupa video animasi yang berisikan tentang beberapa Standard Operating Procedure (SOP) yang telah di pilih untuk di buatkan video animasi. Video animasi ini mampu menampilkan animasi dalam 2 dimensi. Video animasi ini juga bisa di jadikan sebagai media untuk penyampaian informasi menjadi lebih menarik.
\end{abstract}

Kata kunci: Standard Operating Procedure (SOP) Metodologi Penelitian, Video, Animasi Infografis, Animasi 2 Dimensi.

\begin{abstract}
This research was aimed to design and implement the design result of SOP video of kinds of research for course of research methodology which is based on infographic animation. The design of this video was aimed to give information around Standard Operating Procedure (SOP) of research to all students that want or on the process of learning educational research methodology. The research used was Research and Development (R\&D), to develop kinds of research for research methodology which was based on infographic animation. The model used in developing this technology was ADDIE model. The steps of ADDIE model were analysis, design, development, implementation, and evaluation. The results of the ADDIE model are in the analysis phase of problem and solusion analysis, then in the design stage done the storyboard design, character and layout, the development stage is done recording, character modeling, texturing, rigging, animation and rendering and followed by editing stage, Implementation is done by expert test of content, media and field test and finally at evaluation stage done at every development stage. From the development stage final result of this study was in the form of video which contained several SOP which had been chosen as the part that was made the animation video. This animation video could show animation in two dimension. This animation video also could be used as a media to deliver information in a attractive way.
\end{abstract}

Key words : SOP of research methodology, video, infographic animation, animation of 2 dimension 


\section{PENDAHULUAN}

IImu pengetahuan merupakan sebuah sarana atau definisi tentang alam semesta yang diterjemahkan kedalam bahasa yang bisa dimengerti oleh manusia sebagai usaha untuk mengetahui dan mengingat tentang sesuatu (Ahadi, 2012). Untuk memperoleh pengetahuan maka manusia perlu melakukan tahapan perubahan dari tidak mengerti menjadi mengerti dari tidak memahami menjadi memahami dimana tahapan ini disebut proses belajar. Hal ini sesuai dengan definisi belajar menurut Reber (Widodo, 2014) dimana beliau menyatakan bahwa belajar merupakan proses memperoleh pengetahuan. Dalam memperoleh pengetahuan manusia menggunakan gaya yang berbeda - beda tergantung gaya belajar yang dianggap gampang untuk membuat mengerti. Beberapa gaya yang dipilih oleh seseorang disebut modalitas belajar, di mana menurut De Porter gaya belajar berdasarkan modalitas seseorang dibagi menjadi tiga kelompok yaitu, modalitas visual (belajar dengan cara melihat), modalitas auditorial (belajar dengan cara mendengar) dan kinestetik (belajar dengan cara bekerja bergerak dan menyentuh)(Suhara, 2013). Dari ketiga modalitas tersebut yang paling efektif adalah modalitas visual, di mana modalitas ini lebih cenderung suka membaca.

Membaca merupakan hal yang paling efektif untuk menambah pengetahuan terutama pada dunia pendidikan. Membaca menjadi hal pokok yang harus dilakukan oleh seorang pelajar, membaca membuat kita menjadi mandiri untuk memperoleh pengetahuan. Namun di zaman sekarang ini sangat jarang pelajar yang memiliki minat membaca, hal ini dapat dilihat dari indeks membaca orang Indonesia yang dikeluarkan Badan Pusat Statistic (BPS) pada tahun 2012 dijelaskan bahwa 96,68 \% penduduk berusia 10 tahun ke atas lebih suka menonton televisi dan hanya 17,66 persen yang suka membaca. Berdasarkan data United Nations Educational Scientific and Cultural Organization (UNESCO) atau Organisasi Pendidikan IImiah dan Kebudayaan PBB, pada 2012, indeks minat membaca masyarakat Indonesia baru mencapai angka 0,001 . Artinya, dari setiap 1.000 orang Indonesia hanya ada 1 orang yang punya minat baca (Putra, 2015). Salah satu penyebab rendahnya tingkat membaca dikarenakan kebiasaan yang dibiasakan saat belajar di jenjang pendidikan SMP sampai SMA, dimana pada jenjang ini kita dimanjakan dengan materi yang sudah di rangkum oleh guru. Kebiasaan tersebut masih dibawa ke bangku kuliah sehingga mahasiswa menjadi malas untuk mencari referensi materi kuliah dengan cara membaca buku apalagi materi kuliah tersebut terbilang padat, deskriptif dan variatif.

Salah satu contoh mata kuliah yang memiliki materi yang padat, deskriptif dan variatif adalah mata kuliah metodologi penelitian pendidikan. Metodologi merupakan suatu cabang ilmu pengetahuan yang mempersoalkan mengenai langkah - langkah menggunakan metode untuk memecahkan masalah yang dihadapi (Sukardi, 2003). Langkah - langkah metode penelitian ini biasanya disebut dengan Standard operating prosedur (SOP) Penelitian. SOP dalam penelitian dapat dikatakan sebagai acuan kerja / langkah - langkah dalam melakukan sebuah penelitian, kegiatan SOP dalam penelitian meliputi mencari, mencatat, merumuskan, menganalisis dan menyusun laporan. Secara akademis permasalahan lain yang dapat terpecahkan dengan cara penerapan SOP adalah mengenai urusan akademik di fakultas hal ini sejalan dengan penelitian yang dilakukan oleh Virgo Sastrawan tentang pengengembangan SOP Fakultas Teknik dan Kejuruan Universitas Pendidikan Ganesha.

Berdasarkan hasil wawancara yang dilakukan dengan ibu Dr. Ketut Agustini,M.Si selaku dosen pembimbing dan pengampu mata kuliah metodologi penelitian pendidikan (MPP) terdapat beberapa permasalahan yang ditemukan selama mengajar mata kuliah metodologi penelelitian diantaranya :

1. Masih terdapat beberapa mahasiswa yang masih bingung membedakan topik penelitian, hal ini terlihat jelas 
dari hasil penilaian tugas mata kuliah metodologi penelitian yang dapat dilihat pada Lampiran 2, dimana ada beberapa mahasiswa yang tidak bisa membedakan topik eksperimen dengan PTK kemudian topik rekayasa pendidikan dengan rekayasa informatika. Padahal untuk membedakan topik penelitian bisa dilihat dari metodologi penelitiannya.

2. Mahasiswa malas untuk mencari referensi sendiri sehingga mahasiswa kurang memahami prosedur pada masing - masing metode penelitian yang ada. Hal ini dapat dilihat dari banyaknya pertanyaan tentang metode penelitian yang ditanyakan secara berulang - ulang oleh mahasiswa yang berbeda saat melakukan bimbingan penelitian. Kemalasan mahasiswa dalam mencari referensi merupakan effect dari minat membaca mahasiswa yang rendah.

3. Media yang membahas masing masing prosedur penelitian belum banyak dan belum ada media yang dapat menyederhanakan materi metodologi penelitian dan jika ada maka masing - masing media yang membahas jenis metode penelitian ini terpisah pisah sehingga susah untuk mengumpulkan media tersebut.

Menyikapi masalah yang terjadi, maka diperlukan solusi untuk menarik minat mahasiswa sehingga bisa memahami metode penelitian yang ada beserta prosedurnya. Solusi yang dapat dilakukan adalah dengan mengembangkan media visual berupa video animasi infografis, dimana media visual ini dapat menyampaikan informasi yang padat menjadi sederhana namun tidak menghilangkan makna sebenarnya, hal ini sejalan dengan saran yang diberkan oleh Agustini (2012) dimana perlu dikembangkan lebih banyak lagi media-media pembelajaran berbasis model dan simulasi untuk membantu mahasiswa yang memiliki kemampuan abstraksi yang kurang dalam materimateri perkuliahan yang cukup abstrak terutama di bidang ilmu informatika
Salah satu media visual yang saat ini paling efektif dalam menyampaikan informasi adalah media visual berupa video infografis. Dimana menurut house of infographics (Yudhanto, 2015) menyatakan bahwa infografis adalah bentuk visualisasi data yang menyampaikan informasi kompleks kepada pembaca agar dapat dipahami dengan lebih mudah dan cepat . infografis sebagai produk desain komunikasi visual, merupakan hasil solusi tentang penyederhanaan konsep komunikasi.

Perancangan informasi dalam bentuk grafis diawali dari permasalahan komunikasi yang verbal, di mana penyampaian informasi tekstual yang tersusun panjang lebar dan kompleks cenderung kurang dipahami, informasi tekstual kemudian diubah menjadi susunan grafis yang lebih ringkas namun masih relevan dengan konten awal. Infografis memiliki keunggulan dari segi visualnya yang mampu mengubah persepsi audien tentang deskripsi yang panjang menjadi lebih singkat dan jelas melalui elemen grafis. Infografis melakukan penyusunan informasi yang semula rumit menjadi lebih singkat, jelas dan lebih menarik. Berdasarkan hal tersebut, infografis bisa menjadi media yang efektif untuk mewakili data informasi agar tepat mengenai audien/ penerima informasi, sehingga dapat dengan mudah memberikan informasi - informasi yang dibutuhkan dalam bahasa yang lebih sederhana serta mudah dipahami oleh penerima informasi khususnya mahasiswa di mana informasi berupa rangkaian visual dan verbal yang saling bersinergi.

Salah satu hal yang paling menonjol dalam infografis adalah karakteristik kontennya yang memiliki sifat edukatif dan informatif dalam setiap temanya (Pahlevi, 2013). Potensi infografis dalam konteks ini ialah membantu memberikan pengetahuan kepada penerima informasi dalam hal ini adalah mahasiswa. Kemudian dalam keperluan tertentu, infografis dapat didesain tidak hanya informatif, namun juga memiliki kekuatan persuasif. bahkan sebuah infografis yang baik dapat berpotensi menjadi alat 
penyampaian informasi yang efektif untuk digunakan.

Adapun beberapa jenis penelitian terkait berupa pemanfaatan infografis diantaranya penelitian oleh Karinia Mulyate (2013) dalam penelitiannya yang berjudul "Perancangan Buku Kumpulan Infografis Resep Aneka Hidangan Pembuka Dan Penutup Ala Barat Untuk Anak-Anak". Hasil dari penelitian ini berupa buku resep hidangan ala barat. Dimana isi dalam buku resep ini terdapat 7 resep hidangan pembuka dan hidangan penutup ala barat yang praktis dan 6 tips yang sangat membantu anak-anak dalam proses memasak. Hambatan dalam proses perancangan buku yaitu mencari gaya visual yang sesuai dengan target audience, karena dalam membuat suatu buku infografis juga diperlukan visual yang dapat membantu anak-anak untuk memahami informasi yang terdapat didalam buku tersebut. Penelitian lainnya oleh Susetyo pada tahun 2015 dalam penelitiannya yang berjudul "Efektivitas Infografis Sebagai Pendukung Mata Pelajaran IPS Pada Siswa Siswi Kelas 5 Sdn Kepatihan Di Kabupaten Bojonegoro". Hasil yang di dapat dari penelitian ini adalah meningkatnya daya serap peserta didik terhadap pelajaran yang di sampaikan dan perubahan nilai menjadi lebih baik dari angkatan sebelumnya dan penggunaan infografis terbukti efektif dengan hasil yang di tampilkan dari uji hipotesis.

Berdasarkan latar belakang yang diuraikan diatas dan untuk mempermudah mahasiswa dalam mempelajari dan memahami alur proses kerja (SOP) pada masing - masing jenis penelitian maka dikembangkan sebuah SOP Berbasis Infografis Jenis - Jenis Penelitian Untuk Perkuliahan Metodologi Penelitian Pendidikan

\section{METODE}

Penelitian dapat dibedakan berdasarkan metodenya, namun secara umum ada 4 jenis metode penelitian yang sering digunakan, di mana 4 jenis penelitian tersebut yaitu :

1. Penelitian Eksperimen
Eksperimen menurut kerlinger adalah sebagai suatu penelitian ilmiah di mana penelitian memanipulasi dan mengontrol satu atau lebih variabel bebas dan melakukan pengamatan terhadap variabel - variabel terikat untuk menemukan variasi yang muncul bersamaan dengan manipulasi terhadap variabel bebas( Setyanto, 2005).

2. Penelitian Tindakan Kelas

Metode penelitian tindakan kelas menurut David Hopkins (Kunandar, 2008) adalah sebuah bentuk kegiatan refleksi diri yang dilakukan oleh para pelaku pendidikan dalam suatu situasi kependidikan untuk memperbaiki rasionalitas dan keadilan.

3. Research and Development Pendidikan

Menurut Gay (Kantun, 2010), penelitian rekayasa pendidikan merupakan suatu usaha untuk mengembangkan suatu produk yang efektif untuk digunakan sekolah, dan bukan untuk menguji teori.
4. Research

Metode penelitian dan pengembangan atau dalam Bahasa inggrisnya disebut Research and Development adalah metode penelitian yang digunakan untuk menghasilkan produk yang dalam hal ini adalah produk dalam bidang informatika dan menguji produk tersebut (Sugiyono, 2012).

SOP merupakan serangkaian instruksi yang menggambarkan pendokumentasian dari kegiatan yang dilakukan secara berulang pada sebuah organisasi. SOP dalam penelitian merupakan langkah kongkrit yang diambil untuk menjadi pedoman pengerjaan sebuah penelitian. suatu set instruksi yang memiliki kekuatan sebagai suatu petunjuk pekerjaan. (Bhavati, 2014). SOP (Standard Operating Procedure) metodologi penelitian merupakan Instruksi-intruksi yang menggambarkan kegiatan yang dilakukan dalam melakukan tugas-tugas dalam melakukan penelitian. SOP itu sendiri haruslah jelas dan harus dipahami oleh civitas akademika, SOP berfungsi sebagai pedoman kerja supaya tahapan pengerjaan menjadi jelas dan lebih efisien. 
Mark Smicklas berpendapat bahwa banyak orang telah mengenal infografis sebagai representasi statistik karena popularitas visualisasi data, namun para pemasar, manajer dan pemilik bisnis cenderung melihatnya dalam konteks komunikasi pesan dan menggunakan untuk tipe informasi lainnya (Pahlevi, 2013).

Pengembangan SOP Berbasis Infografis Jenis - Jenis Penelitian Untuk Perkuliahan Metodologi Penelitian Pendidikan ini menggunakan model ADDIE (Analysis, Design, Development, Implementation, and Evaluation). Model ini dipilih karena merupakan salah satu model perencanaan pembelajaran yang efektif dan efesien serta prosesnya bersifat interaktif, dimana hasil evaluasi setiap fase dapat membawa pengembangan pembelajaran ke fase sebelumnya. Hasil akhir dari suatu fase merupakan produk awal bagi fase berikutnya. Model ADDIE ini terdiri 5 tahapan pengerjaan yaitu Analysis (Analisis), Design (perancangan), Development (pengembangan), Implementation (implementasi), dan Evaluation (evaluasi). Siklus model ADDIE dapat dilihat pada Gambar 1.

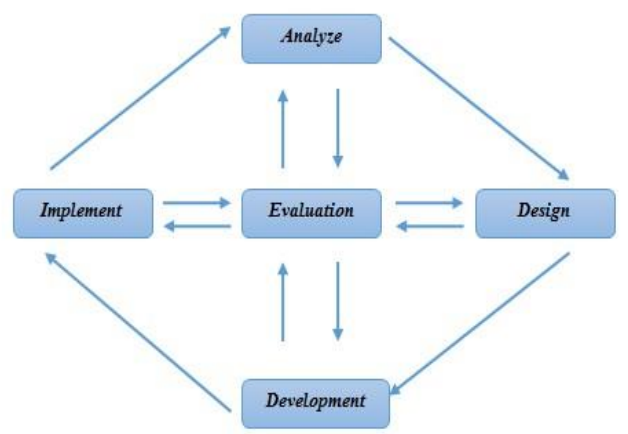

Gambar 1 Tahapan Model ADDIE

\section{A. Analysis (Analisis)}

Pada tahap analisis pengembang melakukan analisis permasalahan yang ada dengan cara mengumpulkan data dari buku, jurnal, dan penelitian yang pernah dilakukan sebelumnya yang berkaitan dengan pengembangan SOP Berbasis Infografis Jenis - Jenis Penelitian Untuk Perkuliahan Metodologi Penelitian Pendidikan. Pada tahap ini dilakukan juga analisis terhadap kebutuhan fungsional dan non fungsional perangkat lunak.

\section{B. Design (Desain)}

Tahap Desain menggunakan output dari tahap Analisis untuk merencanakan strategi untuk mengembangkan video animasi. Dalam tahapan design pada metode ADDIE dilakukan pra produksi pembuatan video atau animasi. Pada tahap Pra Produksi animasi ini belum dibuat, tetapi persiapan atau perencanaan yang akan diperlukan dalam pembuatan video ini, adapun yang direncanakan sebagai berikut. Perancangan naskah, pembuatan storyboard, perancangan karakter dan layout.

\section{a. Perancangan karakter}

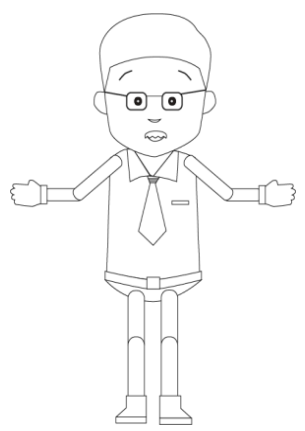

(a)

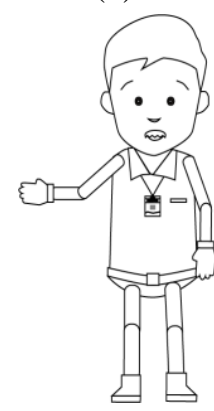

(c)

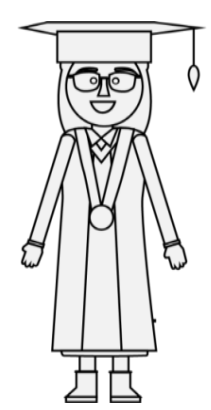

(b)

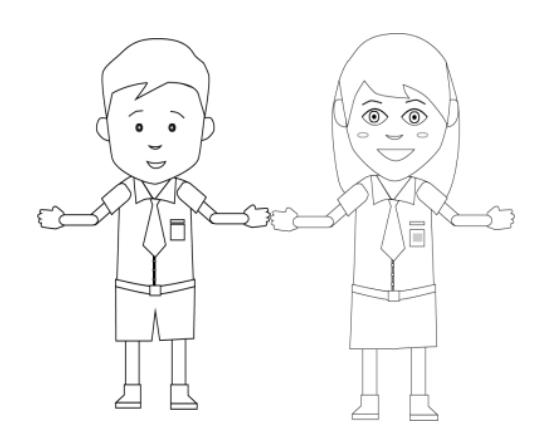

(e)

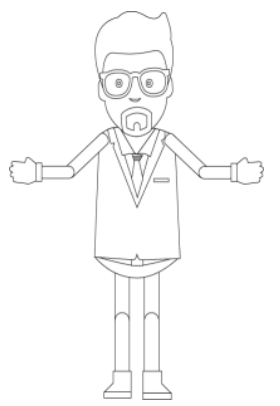

(d) (f) 
Gambar 2. Rancangan Karakter (a) guru,

(b) profesor penelitian (c) penguji ,(d) dosen, (e) siswa 1, (f) Siswa 2.

b. Perancangan Layout

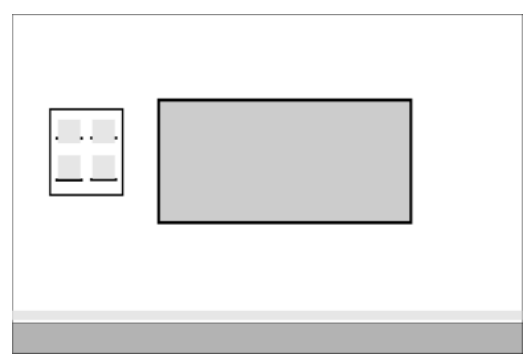

(a)

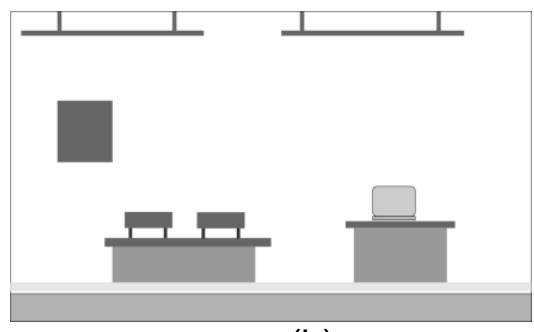

(b)

Gambar 3. Rancangan Layout (a) layout ruang kelas, (b) layout ruang pengujian \& ruang guru.

\section{Development (Pengembangan)}

Rancangan telah dibuat pada tahap design kemudian dikembangkan. Rancangan video SOP Metodologi Penelitian Berbasis Animasi infografis diimplementasikan menggunakan software animasi. Terdapat 2 fase pengembangan yaitu : fase produksi dan fase pasca produksi.

a) Produksi (Pembuatan)

Pada Tahapan produksi / pembuatan video SOP Metodologi Penelitian di buat sesuai kebutuhan awal yang sudah di rancang. Adapun hal yang dilakukan di tahapan produksi adalah pembuatan modelling, texturing, rigging, animation dan rendering $2 \mathrm{D}$ per scane sesuai yang sudah di rencanakan pada tahap design.

b) Pasca Produksi (Editing)

Tahap pasca produksi / editing ini merupakan tahapan yang sangat penting. Karena pada tahap inilah semua gerakan - gerakan animasi 2D yang telah dibuat akan disusun sesuai rancangan yang telah dibuat serta diberi effect dan audio sehingga video akan lebih menarik dan mudah dipahami.

D. Implementation (Implementasi)

Tahap Implementasi adalah tahap dimana aplikasi telah siap untuk diterapkan dan dilakukan pengujian kelayakan. Pengujian ini dilakukan dengan tujuan untuk memastikan video yang telah dibangun berdasarkan rancangan yang dibuat dapat berjalan dengan baik.

E. Evaluation (Evaluasi)

Tahap evaluation merupakan tahap yang dilakukan untuk mengevaluasi proses pengembangan produk sesuai

dengan model yang digunakan. Pada tahap ini hanya digunakan evaluasi yang bertujuan untuk mengumpulkan data tentang efektivitas dan efisiensi media untuk mencapai tujuan yang ditetapkan.

\section{HASIL DAN PEMBAHASAN}

\section{A. HASIL}

1. Hasil Tahap Analyze (Analisis)

Pada tahap ini, peneliti mengidentifikasi masalah-masalah yang ditemukan sehingga dapat dijadikan acuan untuk mengembangkan video SOP Berbasis Infografis Jenis - Jenis Penelitian Untuk Perkuliahan Metodologi Penelitian Pendidikan. Pada tahap ini akan dijelaskan analisis masalah dan solusi yang dilakukan dengan metode wawancara dan observasi yang dilakukan, ditemukan beberapa masalah sebagai berikut.

1. Mahasiswa dalam melakukan penelitian membutuhkan waktu yang lebih lama karena tidak mengetahui SOP metodo penelitian.

2. Metodologi memiliki materi yang padat dan deskriptif sehingga mahasiswa menjadi malas untuk membaca materi terkait tentang metodologi penelitian khususnya SOP metode penelitian.

3. Belum ada media pembelajaran yang membahas tentang metodologi penelitia secara lebih menarik dan ringan.

Berdasarkan analisis masalah di atas maka solusi yang dapat diusulkan adalah pengembangan media berupa video SOP Berbasis Infografis Jenis - Jenis Penelitian Untuk Perkuliahan Metodologi 
Penelitian Pendidikan yang akan dikembangkan ini akan dapat menangani permasalahan yang menjadi temuan peneliti tersebut adalah sebagai berikut.

1. Video SOP Berbasis Infografis Jenis - Jenis Penelitian Untuk Perkuliahan Metodologi Penelitian Pendidikan akan menampilkan informasi yang lebih ringan sehingga mahasiswa lebih mudah memahami prosedur penelitian.

2. Video SOP Berbasis Infografis Jenis - Jenis Penelitian Untuk Perkuliahan Metodologi Penelitian Pendidikan di lengkapi dengan narasi, text dan musik pengiring sehingga akan lebih menarik

Pengembangan SOP Berbasis Infografis Jenis - Jenis Penelitian Untuk Perkuliahan Metodologi Penelitian Pendidikan menggunakan beberapa perangkat lunak dan perangkat keras sebagai berikut.

a. Spesifikasi Perangkat Lunak

Pengembangan SOP berbasis infografis jenis - jenis penelitian untuk perkuliahan metodologi penelitian pendidikan dikembangkan dan diimplementasikan pada lingkungan sebagai berikut.

1. Sistem Operasi Microsoft Windows7 Ultimate.

2. Adobe llustrator CS6

3. Audacity 2.0

4. Adobe After Effect CS6

5. Adobe Premier Pro Cs6

b. Spesifikasi Perangkat Lunak

Untuk dapat diimplementasikan, maka kebutuhan minimum perangkat keras harus dimiliki untuk dapat mengembangkan animasi infografis ini adalah dengan spesifikasi minimal:

1. Laptop Asus A43S 32-bit dual core 2Ghz CPU with SSE2 support.

2. 6 GB RAM

3. 24 bits $1280 \times 768$ display

4. Mouse or trackpad

5. OpenGL 2.1 compatible graphics with 512 MB RAM

6. NVDIA Geforce $2 \mathrm{~GB}$

2. Hasil Tahap Design (Desain)

Pada tahap evaluasi design ini, didapatkan hasil dari perancangan naskah, storyboard animasi yang terdiri dari storyboard dan implementasi design karakter dan implementasi layout animasi.

a. Implementasi Karakter

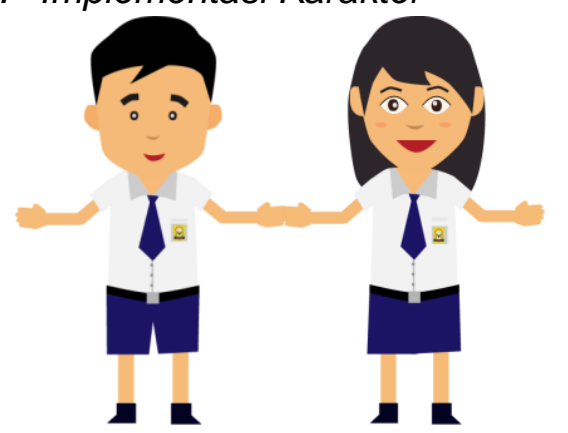

(a)

(b)

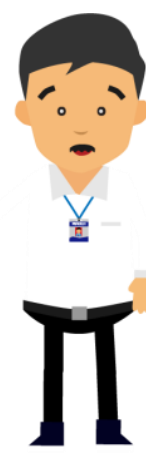

(c)

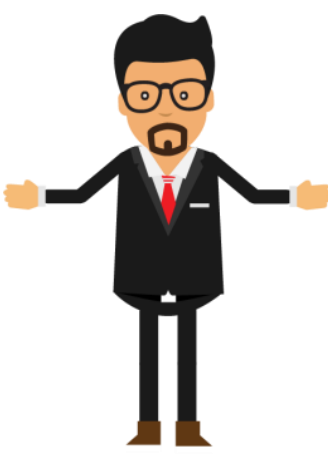

(d)

Gambar 4. Hasil Implementasi Karakter

(a) profesor penelitian, (b) Guru (c)

Penguji ,(d) dosesn, (e) siswa 1, (f) Siswa 2.

b. Implementasi Layout

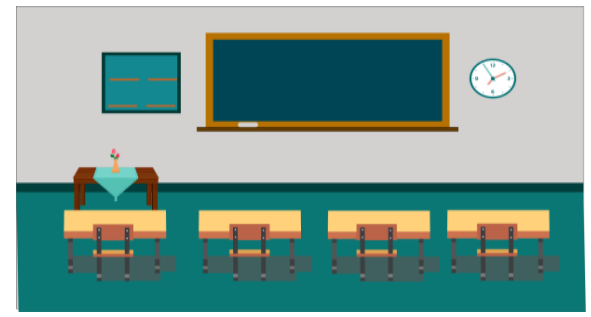

(a)

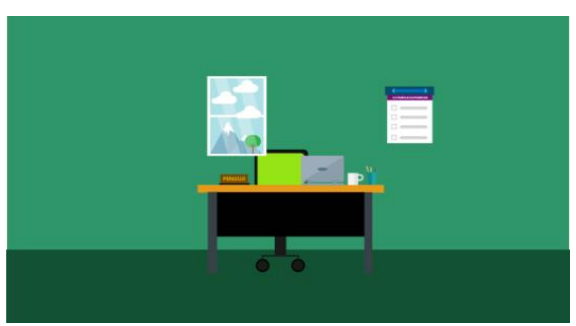

(b) 
Gambar 5. Hasil Implementasi Layout (a) layout ruang kelas, (b) layout ruang pengujian \& ruang guru.

\section{Hasil Tahap Development} (Pengembangan)

Tahapan evaluasi development ini dilakukan dengan melakukan pembuatan animasi pengembangan SOP Berbasis Infografis Jenis - Jenis Penelitian Untuk Perkuliahan Metodologi Penelitian Pendidikan. Terdapat 2 fase pengembangan yaitu : fase produksi dan fase pasca produksi.

a. Pengembangan Fase Produksi

1. Modelling

Modelling merupakan

proses pembuatan objek ke dalam bentuk 2 dimensi. Objek yang dibuat berupa karakter dan juga latar atau layout. Dalam pembuatan karkter 2D menggunakan software Adobe llustrator.

\section{Texturing}

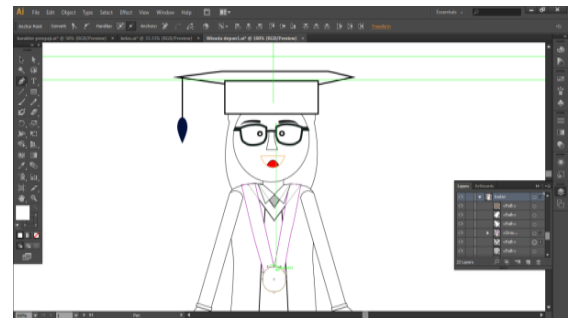

Gambar 6.Modeling Karakter 2D dibuat,

Setelah tahap modelling selesai tahap selanjutnya yaitu memberikan material atau texture pada objek dimensi atau biasa disebut dengan tahap texturing. Texturing karakter 2 Dimensi pada Adobe llustrator cukup dengam memberiakan warna sesuai dengan karakter 2D.

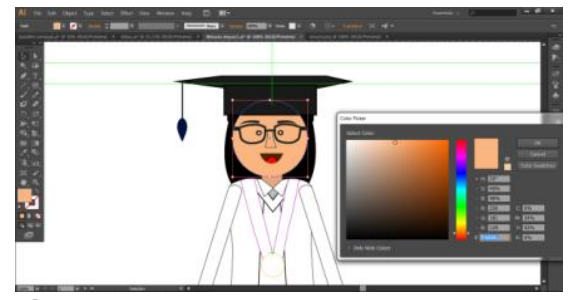

Gambar 7.Texturing Karakter 2D

\section{Rigging}

Rigging adalah proses pemberian struktur tulang pada objek 2 dimensi dengan pemberian tanda dengan pappet pin tool yang terdapat pada software Abobe After Effect.

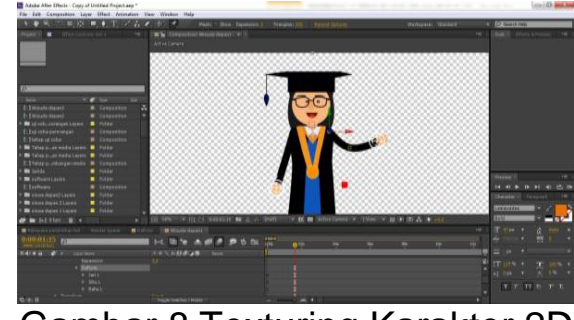

Gambar 8.Texturing Karakter 2D

4. Animation

Pada tahap ini dilakukan proses pembuatan animasi, baik itu berupa gerak karakter, gerak objek pendukung karakter maupun gerak kamera. Proses animasi dilakukan frame by frame dengan menggunakan 25 fps (frame per secon).

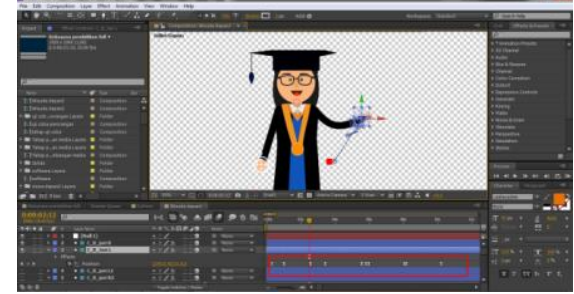

Gambar 8. Pembuatan Animation

\section{Rendering}

Tahap rendering merupakan tahap akhir dari keseluruhan proses produksi. Tahap-tahap yang telah dilakukan sebelumnya akan diterjemahkan ke dalam bentuk output baik itu berupa gambar atau video. Sebelum melakukan rendering untuk 2 dimensi.

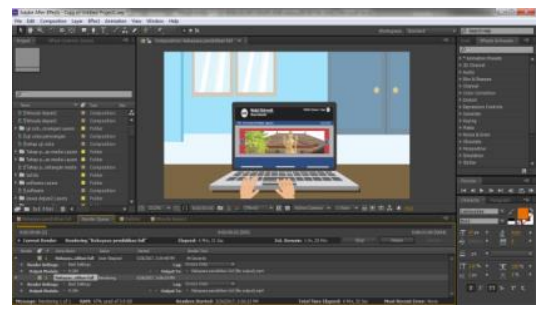

Gambar 9.Proses Rendering

a. Pengembangan Fase Pasca Produksi

1. Tahap perekaman

Tahap perekaman merupakan proses pengambilan suara yang akan digunakan pada animasi yang sering di namakan dubbing. Pada Pengembangan SOP Berbasis Infografis Jenis - Jenis Penelitian Untuk Perkuliahan Metodologi Penelitian Pendidikan ini dilakukan dubbing untuk narasi cerita dan pengisi suara karakter.

2. Tahap editing

Tahap editing merupakan tahap akhir yaitu kita menggabungkan seluruh video 
hasil dari proses rendering dan juga audio dubbing yang telah direkam sehingga menjadi sebuah video yang utuh.

\section{Hasil Tahap Implementation (Implementasi)}

a. Hasil Uji Ahli Isi

Pada tahap uji coba ini, dilakukan oleh Pengembang SOP SOP Berbasis Infografis Jenis - Jenis Penelitian Untuk Perkuliahan Metodologi Penelitian Pendidikan dengan hasil secara umum sudah dapat dikatakan sesuai atau layak. Meski terdapat beberapa dari animasi yang belum sesuai namun sudah segera di revisi sehingga menjadi $100 \%$ sesuai.

b. Hasil Uji Ahli Media

Pada tahap uji coba ini, dilakukan oleh Pengembang SOP SOP Berbasis Infografis Jenis - Jenis Penelitian Untuk Perkuliahan Metodologi Penelitian Pendidikan dengan hasil secara umum sudah dapat dikatakan $99 \%$ sesuai atau layak.

c. Hasil Uji Respon Pengguna

Hasil Respon Pengguna dilakukan untuk mengetahui kepuasan memainkan dan tanggapan pengguna tentang Pengembang SOP Berbasis Infografis Jenis - Jenis Penelitian Untuk Perkuliahan Metodologi Penelitian Pendidikan Uji respon pengguna dilakukan dengan cara menyebarkan angket kepada 36 orang mahasiswa jurusan yang ada di Universitas Pendidikan Ganesha setelah menonton video animasi SOP SOP Berbasis Infografis Jenis - Jenis Penelitian Untuk Perkuliahan Metodologi Penelitian Pendidikan di dapatkan hasil yang di peroleh dari uji respon pengguna di ketahui bahwa skor yang diperoleh adalah 1557 dengan persentase 86,3 , hasil persentase ini dapat dilihat bahwa video animasi SOP yang dikembangkan sudah termasuk kategori baik.

\section{Hasil Tahap Evaluation (Evaluasi)}

Berdasarkan hasil pengujian yang telah dilakukan pada kasus uji ahli isi 1 dan uji ahli isi 2, Pengembang SOP Berbasis Infografis Jenis - Jenis Penelitian Untuk Perkuliahan Metodologi Penelitian Pendidikan semua proses atau prosedur yang di buatkan bentuk animasi sudah sangat bagus dengan koefisien validitas isi instrumen adalah 1.00, meski ada beberapa video animasi yang mendapatkan tidak sesuai dengan prosedur SOP Berbasis Infografis Jenis Jenis Penelitian Untuk Perkuliahan Metodologi Penelitian Pendidikan, namun sudah di revisi dengan segera sehingga bisa di katakana layak atau sesuai.

Pada Uji Ahli Media 1 dan Uji Media 2 terdapat beberapa aspek-aspek yang di ujikan untuk menguji kelayakan produk video untuk digunakan oleh pengguna. Berdasarkan hasil yang diperoleh dapat disimpulkan bahwa Pengembang SOP Berbasis Infografis Jenis - Jenis Penelitian Untuk Perkuliahan Metodologi Penelitian Pendidikan ini, layak digunakan oleh pengguna yang memiliki manfaat sebagai pemberian informasi mengenai SOP (Standard Operating Procedure) metodologi penelitian pendidikan.

Tabel 1. Tabulasi Uji Ahli isi

\begin{tabular}{|c|c|c|c|}
\cline { 3 - 4 } \multicolumn{2}{c|}{} & \multicolumn{2}{c|}{ Penilai 1 } \\
\cline { 3 - 4 } \multicolumn{2}{c|}{} & $\begin{array}{c}\text { Kurang relevan } \\
\text { (skor 1-2) }\end{array}$ & $\begin{array}{c}\text { Relevan } \\
\text { (skor 3-4) }\end{array}$ \\
\hline \multirow{3}{*}{$\begin{array}{c}\text { Penilai } \\
2\end{array}$} & $\begin{array}{c}\text { Kurang relevan } \\
\text { (skor 1-2) }\end{array}$ & (A) & (B) \\
\cline { 2 - 4 } & $\begin{array}{c}\text { Relevan } \\
\text { (skor 3-4) }\end{array}$ & 0 & 0 \\
\hline
\end{tabular}

Tabel 2. Tabulasi Uji Ahli media

\begin{tabular}{|c|c|c|c|}
\cline { 3 - 4 } \multicolumn{2}{c|}{} & \multicolumn{2}{c|}{ Penilai 1 } \\
\cline { 3 - 4 } \multicolumn{2}{c|}{} & $\begin{array}{c}\text { Kurang relevan } \\
\text { (skor 1-2) }\end{array}$ & $\begin{array}{c}\text { Relevan } \\
\text { (skor 3-4) }\end{array}$ \\
\hline \multirow{3}{*}{$\begin{array}{c}\text { Penilai } \\
2\end{array}$} & $\begin{array}{c}\text { Kurang relevan } \\
\text { (skor 1-2) }\end{array}$ & (A) & (B) \\
\cline { 2 - 4 } & $\begin{array}{c}\text { Relevan } \\
\text { (skor 3-4) }\end{array}$ & 0 & 1 \\
\hline
\end{tabular}

Tabel 3. Kualifikasi Nilai dari Masing Masing Responden

\begin{tabular}{|c|c|c|c|}
\hline NO & Responden & Koefisien & Kualifikasi \\
\hline 1 & Uji AhliIsi & 1,00 & Sangat Tinggi \\
\hline 2 & Uji Ahli Media & 0,92 & Sangat Tinggi \\
\hline
\end{tabular}

\section{B. Pembahasan}

Pengembangan video SOP berbasis infografis jenis - jenis penelitian untuk perkuliahan metodologi penelitian pendidikan bertujuan untuk membantu mahasiswa dalam memahami prosedur yang dilakukan dalam melakukan penelitian. Dalam pengembangan video 
SOP berbasis infografis jenis - jenis penelitian untuk perkuliahan metodologi penelitian pendidikan ini menggunakan model ADDIE. Pada tahap analisis pembuatan video SOP berbasis infografis jenis - jenis penelitian untuk perkuliahan metodologi penelitian pendidikan ini diawali dengan melakukan identifikasi permasalahan - permasalahan yang di alami di lapangan dengan cara melakukan observasi dan wawancara dengan ibu Dr. I Ketut Agustini, S.Si.,M.Si selaku pengampu mata kuliah metodologi penelitian pendidikan, dari hasil wawancara di peroleh informasi bahwa terdapat beberapa masalah yang ditemukan dalam proses pembelajaran pada perkuliahan metodologi penelitian pendidikan seperti, masih banyaknya mahasiswa yang susah memahami materi terkait metodologi penelitan yang memiliki materi yang terbilang padat dan deskriptif, kemudian yang kedua adalah masih rendahnya minat membaca mahasiswa sehingga pemahaman pada materi kuliah yang memiliki materi padat dan deskriptif menjadi masih sangat rendah, dan yang ketiga adalah media pembelajaran yang membahas tentang metodologi penelitan masih sangat sedikit. Selanjutnya setelah permasalahan teridentifikasi maka dibuatlah sebuah media yang berupa video animasi berbasis infografis yang membahas tentang SOP metodologi penelitian. Kemudian dilakukan pengumpulan dilakukan pengumpulan data dari buku, jurnal dan penelitian yang terkait video animasi berbasis infografis dan materi metodologi penelitian pendidikan. Selanjutnya setelah proses pengumpulan data selesai maka dilakukan proses analisa kebutuhan yang terdiri dari kebutuhan fungsional dan non fungsional. Akhir tahapan analisis akan dilakukan evaluasi untuk melihat apakah semua kegiatan dalam tahap analisis sudah dilakukan.

Tahap 2 adalah proses pembuatan desain, dimana pada tahapan ini dilakukan pembuatan ide cerita yang kemudian dituangkan menjadi sebuah sinopsis yang menjadi pedoman cerita dalam pembuatan animasi SOP metodologi penelitian, kemudian setelah sinopsis selesai dilanjutkan degan pembuatan narasi sesuai materi yang ada dalam masing masing video SOP metodologi penelitian, kemudian dilanjutkan dengan membuatan storyboard sesuai dengan alur cerita / sinopsis yang sudah dibuat untuk mempermudah dan menjadi pedoman isi cerita dalam proses pembuatan video animasi SOP berbasis infografis. Kemudian setelah storyboard selesai maka akan di buat karakter / tokoh atau layout yang dibutuhkan sesuai sinopsis dan storyboard yang sudah dirancang, Kemudian di akhir tahap desain / perancangan akan dilakukan evaluasi untuk melihat apakah semua rancangan yang dibutuhkan sudah di buat.

Tahap 3 merupakan tahapan Development (Pengembangan) video SOP berbasis infografis jenis - jenis penelitian untuk perkuliahan metodologi penelitian pendidikan, dimana pada tahap ini diawali dengan melakukan pengembangan tahap produksi. Pada tahap produksi dilakukan perekaman suara sesuai narasi yang sudah dirancang, kemudian setelah selesai melakukan perekaman suara/dubing maka dilanjutkan ke tahap pembuatan modeling karakter dan layout 2D sesuai karakter dan layout yang sudah di rancang pada tahap desain, kemudian setelah selesai melakukan modeling dilanjutkan dengan pemberian texture / warna pada karakter dan layout yang dibuat, kemudian dilanjutkan ke tahap riging atau pemberian struktur tulang pada karakter 2D yang telah di buat dengan addon/ asset tulang yang ada pada affter effect, setelah selesai memberikan tulang / riging, dilanjutkan dengan proses pembuatan animasi yang dilakukan pada software after effect, kemudian setelah proses penambahan animation seperti position, scale, rotation, transition, blur kemudian dilanjutkan ke tahap rendering untuk mendapat output berupa video dengan format mp4. Setelah proses rendering selesai maka dilanjutkan ke tahap pasca poduksi, dimana pada tahap ini akan dilakukan proses editing pada animasi yang sudah dirender menjadi video dengan cara menggabungkan seluruh scene yang ada sesuai urutan yang telah di rancang kemudian 
dilanjutkan dengan pemberian effect suara dan backsound yang menarik dan sesuai dengan isi vidio animasi infografis pada software adobe premier. Setelah selesai editing maka dilanjutkan ke tahap evaluasi terhadap tahap pengembangan yang dilakukan.

Tahap 4, merupakan tahapan Implementation (Implementasi), dimana pada tahap ini dilakukan uji ahli isi dan media dari video SOP berbasis infografis jenis - jenis penelitian untuk perkuliahan metodologi penelitian pendidikan yang sudah di buat. Hasil uji ahli isi terhadap video SOP berbasis infografis jenis - jenis penelitian untuk perkuliahan metodologi penelitian pendidikan dengan menggunakan angket menunjukan bahwa isi informasi didalam video SOP berbasis infografis jenis - jenis penelitian untuk perkuliahan metodologi penelitian pendidikan adalah sudah "sesuai" dan layak uji media dengan revisi. Kemudian dilanjutkan ke tahap selanjutnya yaitu tahap uji ahli media. Hasil uji media video SOP berbasis infografis jenis - jenis penelitian untuk perkuliahan metodologi penelitian pendidikan berdasarkan pengujian yang dilakukan oleh 2 orang yang dinyatakan "sesuai" dan layak uji coba lapangan dengan revisi. Uji respon pengguna adalah pengujian untuk mengetahui bagaimana respon dari pengguna setelah menonton video SOP berbasis infografis jenis - jenis penelitian untuk perkuliahan metodologi penelitian pendidikan sebenarnya akan menggunakan pengujian user experience (UX). Akan tetapi, belum bisa terlaksana dikarenakan penulis belum bisa mendapatkan butir pernyataan instrumen dan keterbatasan waktu penelitian. Sehingga uji ahli respon dilakukan dengan menggunakan uji skala likert. Uji respon dilakukan terhadap 36 orang responden yang merupakan mahasiswa di lingkungan UNDIKSHA. Hasil uji reponden didapatkan bahwa total presentase yang diperoleh adalah 1557 dengan persentase 86,5\% yang dikonversikan kedalam tabel konversi menyatakan "baik"

Berdasarkan pembahasan diatas dapat ditarik kesimpulan bahwa informasi pada video SOP berbasis infografis jenis - jenis penelitian untuk perkuliahan metodologi penelitian pendidikan dapat tersampaikan dengan baik. Serta mendapatkan respon yang sangak baik dari pengguna. Video SOP berbasis infografis jenis - jenis penelitian untuk perkuliahan metodologi penelitian pendidikan sejalan dengan penelitian Arinata (2016) dengan perancangan video infografis animasi interaktif tentang prosedur pemberangkatan tenaga kerja indonesia berbasis android dan penelitian yang di kembangkan Sastrawan (2017) dengan pengembangan video SOP Fakultas Teknik Dan Kejuruan Universitas Pendidikan Ganesha berbasis animasi. Melalui video SOP berbasis infografis jenis-jenis penelitian untuk perkuliahan metodologi penelitian pendidikan diharapkan dapat menjadi media informasi yang dapat membantu mahasiswa dalam pempelajari SOP Metodologi penelitian dan Dosen sebagai media untuk proses perkuliahan. Penelitian video SOP berbasis infografis jenis - jenis penelitian untuk perkuliahan metodologi penelitian pendidikan mengalami beberapa kendala. Kendala yang dialami diantaranya kekurangan referensi seperti buku maupun jurnal yang membahas tentang video animasi infografis. Kendala lain yang dialami dalam proses pembuatan video ini adalah luasnya pembahasan yang ada dalam metodologi penelitian pendidikan dan terdapat pendapat - pendapat yang berbeda dari beberapa sumber yang ada sehingga harus dilakukan penambahan dan perbaikan narasi, dubing dan animasi secara beberapa kali dan hal ini mengakibatkan waktu penelitian penulis menjadi lebih panjang.

\section{SIMPULAN DAN SARAN}

Berdasarkan hasil analisis, implementasi dan pengujian pada penelitian ini, maka dapat diambil kesimpulan sebagai berikut.

1. Pengembangan SOP Berbasis Infografis Jenis - Jenis Penelitian Untuk Perkuliahan Metodologi Penelitian Pendidikan dirancang menggunakan model ADDIE (Analyze, Design, Development, Implementation, and Evaluation). Pada tahap analisis 
dilakukan studi literatur, observasi dan wawancara untuk mendapatkan kebutuhan perangkat lunak. Hasil tahap analisis digunakan dalam tahap perancangan. Rancangan yang telah dibuat digunakan sebagai acuan dalam tahap pengembangan. Pada tahap pengembangan dilakukan proses pengembangan objek-objek secara 2 dimensi. Di lanjutkan dengan tahap implementasikan pada tahap ini dilakukan Pengujian video animasi.

2. Pengembangan SOP Berbasis Infografis Jenis - Jenis Penelitian Untuk Perkuliahan Metodologi Penelitian Pendidikan dilakukan dengan beberapa cara dan mendapatkan hasil sebagai berikut. Yang pertama yaitu Pengujian Uji Ahli Isi yang mendapatkan hasil persentase sebesar $100 \%$ setelah mengerjakan revisi yang telah di selesaikan dengan baik sehingga bisa dikategorikan sangat baik. Kedua adalah pengujian ahli media yang mendapatkan hasil semua fitur-fitur pada video yang ditampilkan sesuai dengan yang diharapkan dengan kategori sangat baik. Ketiga adalah pengujian uji responden pengguna, dengan mendapatkan hasil uji yang di peroleh dari uji respon pengguna di ketahui bahwa skor yang di dapat adala 1557 dengan persentase 86,3 sehingga dapat dikategorikan baik.

Berdasarkan hasil penelitian pengembangan dan kesimpulan, saran yang dapat diberikan kepada pembaca untuk pengembangan selanjutnya adalah sebagai

berikut.

1. Pengujian respon pengguna untuk penelitian video animasi SOP berbasis infografis akan lebih baik jika menggunakan angket user experience agar pembuat video animas bisa mengetahui kelemahan dari video SOP yang dibuatnya.

2. SOP berbasis infografis jenis - jenis penelitian untuk perkuliahan metodologi penelitian pendidikan ini belum di ketahui seberapa besar pengaruhnya, untuk itu peneliti berharap bahwa ada peneliti lain yang dapat menguji keefektivitasan media berupa video SOP berbasis infografis ini dengan penelitian eksperimen atau PTK.

\section{DAFTAR RUJUKAN}

Agustini, K. (2011). Pengembangan Simulasi Binary Three berbasi CAI dalam pembelajaran Matematika Diskrit. Jurnal Teknologi Pendidikan, 125-135.

Bhavati, A. (2014). Jenis-Jenis SOP (Standar Operating Procedure). Retrieved from Anugerah Dino: http:// www.anugerahdino.com/2014/10/jeni s-jenis-sop-standar-operating.html

Narbuko, D. C., \& Achmadi, D. H. (2013). Metodelogi Penelitian. Jakarta: Bumi Aksara.

Pahlevi, A. S. (2013). perancangan aplikasi infografis dalam kampanye sosial untuk mendukung aktivitas corporate social responsibility de tanjung. Yogyakarta: Institut Seni Indonesia.

Sastrawan, P. V., Arthana, I.K.R., \& Sindu, I.G.P. (2017). Pengembangan SOP Fakultas Teknik dan Kejuruan Universitas Pendidikan Ganesha Berbasis Animasi. Jurnal Pendidikan Teknik Informatika(Karmapati), Vol 6, No 1.

Suhara, A. M. (2013). Keefektifan model VAK Dalam Pembelajaran Menulis Deskriptif. Bandung: Universitas Pendidikan Indonesia.

Sukardi. (2003). Metodologi Penelitian Pendidikan. Yogyakarta: PT. Bumi Aksara

Rinaldi, J. (2012). Perancangan Tutorial Penerimaan Mahasiswa. UNSRAT.

Tornado, H. (2014). Perancangan Media Video Profile. Tanggerang: STIMIK Raharja. 